\title{
ЕПІСТОЛЯРІЙ ЯК АРТЕФАКТ ДУХОВНОСТІ
}

У статті розглянуто проблему духовності, щуо актуалізується у кризові періоди суспільного розвитку, проаналізовано основні теоретикометодологічні засади означеної теми, визначено домінантні засади духовності особистості в епістолярії митців слова. Запропоновано вивчати листи письменника як сучасника своєї епохи, у результаті чого проступає картина духовності чи бездуховності не тільки конкретних дій, думок $i$ вчинків адресатів, а й картина духовності суспільства Окреслено епістолярій як категорію, що демонструє сутнісні формати духовності адресатів, адже саме людині притаманні мислення, свідомість, емоції, переживання.

Ключові слова: епістолярій, духовність, лист, письменницький епістолярій.

Проблематика духовності різко актуалізується на зламі епох, у кризові періоди суспільного розвитку, коли попередні засади людської діяльності значною мірою вичерпали себе, адже загострюються питання про ідеали, сенс, світогляд людини, які зміщені до екзистенційних імперативів. Зміни в духовному житті суспільства, перевага одних цінностей, зменшення ролі інших, якісна трансформація третіх спонукають по-новому осмислювати роль духовності в житті суспільства. Становлення нових форм цінностей відбувається синхронно, з розвитком тих сфер життєдіяльності суспільства, які традиційно відносять до духовних.

«Дух - філософське поняття, що означає не матеріальне начало, на відміну від матеріального, природного начала. Питання про співвіднесеність Духа і матерії - основне питання філософії. Для матеріалізму Дух вторинне, виробниче, «вищий цвіт матерії» (Ф. Енгельс). В ідеалістичних вченнях Дух, першооснова світу, що виступає як поняття (пантогізм), субстанція (пантеїзм), особистість (теїзм, персоналізм). У раціоналізмі визначною стороною Духа вважається мислення, свідомість, усвідомлення, інтуїція і т.д. В давньогрецькій філософії: пневма, нус, логос» $[18,421]$.

Біблійні джерела характеризують «Дух» як третю особу Пресвятої Трійці - Дух Святий. У цьому розумінні він $є$ істинний Бог. На 50-й день по Воскресінню Ісуса Христа, Дух зійшов на апостолів у вигляді вогняного язика [1].

Уперше нерелігійні поняття духовності визначили німецькі філософи Нового часу: І. Кант [7], Г. В. Ф. Гегель [3]. Давньогрецькі філософські системи не відокремлювали душу від матерії, життя матерії обумовлювалось наявністю в ній душі. Суть людської душі ототожнювалася зі світовою рушійною силою (вогнем, за Гераклітом і Левкіппом, повітрям, за Анаксіменом). Піфагорійці вважали душу числом і відокремлювали іiі від 
матерії. Згідно з Платоном, душа посідає проміжне місце між цариною ідей і нижчим світом становлення і зникнення i, таким чином, ій властиві як розум, так і пристрасті. Оскільки душа частково належить царині ідеї, Платон вважав, що вона існує до народження людини і є безсмертною. Неоплатонівці притримувались того ж погляду на душу. Аристотель, філософії якого властиві матеріалістичні елементи, погоджувався в цьому питанні 3 натурфілософами і вважав діяльність душі пов’язаною з життєвим теплом. За його твердженням, душа проникає у кров в образі живильного подиху. Арістотель вважав душу ентилехією (грець. entecheia - завершення) тіла; iii специфічною формою є розум. Перипатетики розвинули ці ідеї $[17,196]$.

На думку С. Кримського, [10, 21-28] духовність виступає як засіб самобудівництва особистості та покликання іiі носія. Світогляд є висхідною формою духовного засвоєння дійсності людиною. Саме через нього світ «відкривається» людині; те, яким він ий «відкривається» залежить від світогляду. Якщо світогляд потребує вибору способу життя, то духовність пов'язана з обиранням особистого способу, своєї долі й ролі, одним словом, iз зустріччю 3 самою собою. Духовність завжди виступає як принцип самобудівництва людини, як вихід до найвищих інстанцій констатування особистості та її менталітету, як поклик до здійснення того, що не здійсниться природним шляхом. Духовність, вважає С. Кримський, - це здатність переводити універсум зовнішнього буття у внутрішній всесвіт особистості на етичних засадах, здатність створювати внутрішній світ. Духовність призводить до свого роду сенсової космогонії, «з'єднання образу світу з моральними законами індивіда» [10, 21-28].

Трактування духовності, власне ऑii бачення зустрічаємо у працях літературознавців. П. Кононенко у книзі «В пошуках суті» роздумує над людським ідеалом, з'ясовує, чи змінюються уявлення про духовність у людей різних епох. Він захоплюється добою Відродження, адже це був найбільш прогресивний переворот в історії людства. Мірилом величі та краси для того часу була Людина, особистість, цільна характером, бездонна почуттями i всесильна розумом. «Творці й зодчі цієї епохи, розбиваючи кайдани рабства, у яке їх заковувало християнство та феодалізм, мріяли стати господарями всесвіту. Вони перші по-справжньому і на основі науки заглибились в єство людини. Принципи гуманізму у той час для багатьох були не лише красивою теорією, а й нормою життя. Тому й стали ці люди предтечами відродження не тільки особи, окремих індивідуальностей, а й цілих народів, мірилом величі й героїзму...» [8, 105-106].

Автор книги вважає, що українські письменники черпали сили саме в епосі Відродження, яка вабила титанізмом гуманістичної концепції, «бо утверджувала їх у вірі в Людину» [8, 124]. Найважливішими етапами літератур світу П. Кононенко називає етапи філософського осмислення та поетичного відтворення характеру людину, викликаного зміною обставин життя. Отже, новизну літератури визначає людина 3 новими думками, почуттями, іiі духовне життя. 
У центрі уваги монографії М. Крюковського «Ното pulcer - Человек прекрасный» - людина у світлі естетичного сприйняття й оцінки. Досліджує автор фізичну та духовну красу людини, дає характеристику цілісної особистості в діалектично суперечливій єдності іiі зовнішнього і внутрішнього, фізичного й духовного з точки зору естетичного ідеалу.

М. Крюковський торкається проблеми духовності в художній літературі, порушує проблемне питання: чи можна в художньому творі всебічно охопити внутрішню красу людини? «Ще Аристотель писав, що «красу душі не можна охопити поглядом, як красу тіла». Останню наш погляд дійсно помічає миттєво й безпомилково, перша ж сприймається й оцінюється повільно й, на жаль, не без помилок. Але духовна краса людини має відносно самостійне існування. Саме цей різновид краси $є$ предметом зображення iï в художній літературі [11, 175-176].

Л. Санов у книзі «Чим вимірюється людина», розглядаючи твори українських письменників, намагається з'ясувати людський ідеал у літературі. «Замислюючись над художньо-естетичними принципами літературної теорії і практики, які забезпечили життєвість і реалістичну силу ряду персонажів..., ми маємо всі підстави підкреслити насамперед духовну цільність, високу соціальну активність героя, широту його кругозору, глибоке розуміння ним свого громадянського обов'язку» $[16,76]$. Він вважає, що фінальною метою творчих зусиль митця має бути людина, іiі образ, характер, духовний світ. При цьому краса сердець, багатство і велич духовного світу особистості повинні бути розкриті не засобами ідеалізації чи лакування, а суворими й жорстокими барвами життєвої правди, яка вбирає в себе і пафос боротьби, і трагічні колізії доби, і радість перемоги, і поезію праці, і революційний порив, і гіркоту втрат, і світлу думу про майбутнє. Людина - єдина істота на Землі, якій притаманна свідомість, духовне життя, а джерелом свідомості є людське буття.

Людина здійснює зв'язок зі світом у трьох формах (практичній, пізнавальній i духовно-практичній) i не просто пристосовується до навколишнього середовища, але й активно перетворює, освоює світ і опановує його закони. Таке активне опанування світом як об'єктом відбувається у формі практичної діяльності (матеріально-предметного перетворення дійсності) і теоретичної, пізнавальної діяльності, засобом і вищою формою якої є мислення. Пізнавальна діяльність, і зокрема мислення, спрямовані на нейтральне, суто об'єктивне зображення світу і людини. Проте людська духовна активність не обмежується лише спрямованістю на об'єкт, на реальність «поза себе». $С$ й інша форма ідеальної діяльності, яка спрямована саме на перебудову людської душі. Це - духовно-практична діяльність, ціннісна форма свідомості. Людську свідомість не можна ототожнювати лише зі знанням, пізнанням, мисленням. За своєю суттю свідомість є здатністю людини не лише пізнавати світ, але й усвідомлювати його, наповнювати сенсом і суб'єктивним значенням, співставляти свої знання з метою власного існування, оцінювати не лише за об'єктивними характеристиками, але і як світ свого життя. Свідомість є усвідомленням 
вчинків, їх наслідків, що нерозривно пов’язано з совістю, з відповідальністю людини за свої стосунки $з$ природою і світом людей.

Переважна більшість дослідників визначає епістолярій як духовну категорію, адже саме людині притаманні мислення, свідомість, емоції, переживання. Деметрій Фалерський наголошував на тому, що кожен, хто пише, дає у листі відображення своєї душі [5, 237-285]. Б. Модзалевський зазначив, що власне письменницькі кореспонденції «розкривають перед нами приховане від усіх єство письменника, оголюючи найпотаємніші сторони його душі і розуму» $[13,4]$. Ж. Ляхова наголошує, що «листи дають насамперед багатющий матеріал для пізнання особистості й духовного світу їх авторів, оточення й епохи, в яку вони жили і працювали» [12, 87]. Дослідниця також зазначає, що лист письменника - передусім «самосвідчення, психологічна інтроспекція, а часом сповідь» $[12,87]$.

Н. Петриченко зазначила: «Листи - це голос розуму й серця письменника, а ознайомлення $з$ ними - шлях до проникнення в духовний світ митця та його героїв, у естетичну тканину твору, осягнення авторської позиції й водночас спонука до самоаналізу та самовиховання читача» [15, 32-37]. Загальна тональність листів краще, ніж будь-який інший матеріал, дає змогу скласти про письменника певне i яскраве уявлення, відчути сутність його особистості, зрозуміти його психічний, внутрішній світ, його світовідчуття i душевний настрій, увійти з ним у безпосереднє, інтимне спілкування $[19,12]$.

Л. Гінзбург наголошувала на тому, що «образ людини формується самим життям і житейська психологія відкладається слідами листів, щоденників, сповідей та інших людських документів», у яких естетичний елемент присутній 3 більшою чи меншою мірою неусвідомленості» [4, 12]. М. Назарук доходить висновку, що листи відбивають і масову й елітарну художню свідомість, тобто $є$ не просто виявом культури в широкому розумінні, а предметом, що вимагає відповідного словесного оформлення, бо перебуває в площині естетично засвоєного світу, норми як прояву краси [14].

М. Коцюбинська визначила, що власне епістоли «виявляють у чистому вигляді справжню суть людини, зокрема людини творчої - письменника, митця. Виявляють його уподобання, його святощі, не приховуючи відтінків, внутрішніх суперечностей, набагато повніше й автентичніше, ніж інші вияви літературно-публіцистичного висловлювання» [9, 40]. «Письменник «розквітає» у листах художньо до людини близької за духом, в чомусь i конгеніальної, коли автор і адресат на одній хвилі - чи то емоційній, чи то інтелектуальній» $[9,152]$.

I. Забіяка відзначає, що листи значною мірою наближаються до щоденникових записів, вони дуже близькі до мемуарів, але є й відмінність між ними: мемуари пишуться поступово, 3 часом можуть змінюватися й, зазвичай, призначаються нащадкам. Листи ж мають сучасний інтерес i пишуться під хвилинним враженням, у них яскраво відображений характер автора, його настрій, духовний і фізичний стан у даний момент [6, 7]. Г. Вервес писав: «досягнемо такого ступеня духовного розвитку, що видамо 
ці документи, як тепер видаємо класику, бо саме в дусі їі благородства, милосердя і людяності все це написано» [2, 30].

Отже, епістолярій митця можемо розглядати через призму вияву духовних, внутрішніх, найпотаємніших запитів, складних світоглядних позицій. Зрештою, через вивчення листів письменника як сучасника своєї епохи, проступає картина духовності чи бездуховності не тільки конкретних дій, думок і вчинків адресатів, а й картина духовності суспільства.

\section{ЛІТЕРАТУРА}

1. Библия. Книги священного Писания Ветхого и Нового Завета. - М.: Библеймкре общество, 1995. - 1371 с.

2. Вервес Г. Д. Поет повертається на Батьківщину // Рад. літературознавство. - 1989. - №1. - С.29-34. С. 30

3. Гегель Г.В.Ф. Феноменология духа: В 14 т. - М. 1959. - Т.4. - 440 с.

4. Гинзбург Л. О психологической прозе. - Л.: Худож. лит., 1976.- 464 с. C.12.

5. Деметрий о стиле //Античные риторки. - М.: Изд-во Моск. ун-та, 1978. - C.237-285.

6. Забіяка I.М. Епістолярна спадщина В.Горленка: Монографія. - К.: ВПЦ „Київський ун-т”, 2002. - 247 с.С.7

7. Кант И. Критика чистого разума. - Симферополь: Реноме. - 1998. - 528 c.

8. Кононенко П.П. У пошуках суті. - К.: Дніпро. 1981. - 87 с.

9. Коцюбинська М. „Зафіксоване й нетлінне”. Роздуми про епістолярну творчість. - К.: Дух і літера, 2001. - 299 с. С. 40.

10. Кримский С.Б. Контуры духовности: Новые контексты идентификации // Вопросы философии. - 1989. - № 12. - С. 21-28.

11. Крюковский H. Нomo pulcer - Человек прекрасный: Очерк теоретической естетики человека. - Минск: Из-во БГУ, 1983. - 303 с.

12. Ляхова Ж. Теоретичні питання дослідження епістолярію українського письменства //Третій Міжнародній конгрес україністів. Харків, 1996. - Том: Літературознавство. - С.85-91. С.87.

13. Модзалевский Б.Л. Предисловие // Пушкин А.С. Письма: В 3 т. М.-Л.: Гос. изд-во, 1926. - Т.1. - 1815-1825. - С. III - XLVII, С. 4.

14. Назарук М.Й. Українська епістолярна проза кінця XVI - початку XVII ст.: Дис...канд. філол. наук: 10.01.01 /НАН України, Ін-т літератури ім. Т.Г.Шевченка. - К., 1994. - 192 с.

15. Петриченко Н. Лист письменників на учнівській парті//Дивослово. - 2004. - № 4. - С. 32-37

16. Санов Л. Чим вимирюється людина. Літературно-критичні роздуми і нотатки. - К.: Рад. пись-к, 1976. - 162 с.

17. Словарь античности: Пер. с нем. - М.; Эллис Лак; Прогресс, 1994. - C. 196]

18. Советский эниклопедический словарь. - 4-е изд. - М.: Сов. Энцикл., 1989. - С. 421 
19. Стасов В.В. Письма. - М.-Л., 1930. - 49 с. С.12

В статье рассмотрена проблема духовности, проанализированы основные теоретико-методологические основы обозначенной темы, определены доминантные основы духовности личности в эпистолярии художников слова. Определен эпистолярий как категория, которая демонстрирует сущностные форматы духовности адресатов.

Ключевые слова: эпистолярий, духовность, письмо, писательский эпистолярий.

The article considers a problem of spirituality, which tends to be urgent when society development undergoes crisis periods. It analyses the main theoretical and methodological principles of the given topic, indicates the dominating principles of the person's spirituality in the author's letters. Studying writer's letters considering him or her as a certain epoch contemporary has been suggested. As a result, the picture of spirituality or spiritual impoverishment of not only the addressee's particular actions and thoughts, but the picture of whole society's spirituality has been outlined. The author's letters are defined as a category which demonstrating the addressee's spirituality, since thinking, consciousness, emotions and feeling are of human nature.

Key words: author's letters, spirituality, letter, writer's letters. 